\title{
Öğretmenlerin Politik Becerileri ile Problem Çözme Becerileri Arasındaki İlişki*
}

\author{
The Relationship Between Teachers' Political Skills and Problem Solving Skills
}

\section{Mustafa ÖZGENEL ${ }^{1}$, Büşra Nur BOZKURT ${ }^{2}$}

${ }^{1}$ Dr.Öğrt.Üyesi, Sabahattin Zaim Üniversitesi, mustafa.ozgenel@izu.edu.tr, (iD 0000-0002-7276-4865

2 Öğretmen, Milli Eğitim Bakanlığı, nurbozkur07@gmail.com , (DD 0000-0003-1645-0041

\begin{tabular}{|c|c|}
\hline \multicolumn{2}{|l|}{ Araştırma makalesi/ Research Article } \\
\hline Geliş: 02.05 .2020 & Yayın: 01.07.2020 \\
\hline $\begin{array}{l}\text { Atıf } \\
\text { Özgenel, M. \& Bozkurt, B. N. (2020). Ö } \\
\text { arasındaki ilişki. Maarif Mektepler } \\
\text { doi:10.46762/mamulebd.731052 }\end{array}$ & 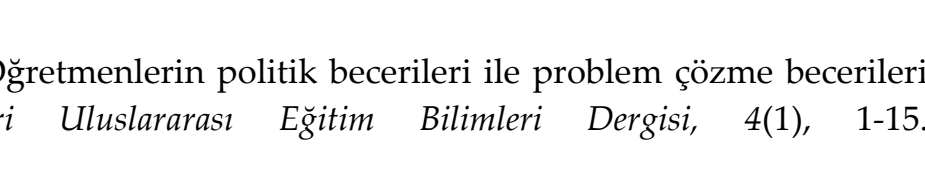 \\
\hline $\begin{array}{l}\text { Özgenel, M. \& Bozkurt, B. N. (2020). Th } \\
\text { solving skills. Maarif Mektepleri In } \\
\text { doi:10.46762/mamulebd.731052 }\end{array}$ & $\begin{array}{l}\text { e Relationship between teachers' political skills and problem } \\
\text { ternational Journal of Educational Sciences, 4(1), } 1-15 \text {. }\end{array}$ \\
\hline
\end{tabular}

Öz

$\mathrm{Bu}$ çalışmanın amacı öğretmenlerin politik becerileri ile problem çözme becerileri arasındaki ilişkiyi belirlemektir. Araştırmanın örneklemini 2018-2019 eğitim-öğretim yılında İstanbul ili devlet okullarında görev yapan 440 öğretmen oluşturmaktadır. Araştırma modeli olarak ilişkisel tarama modeli kullanılmıştır. Veriler Özdemir ve Gören (2015) tarafından Türkçeye uyarlanan "Politik Beceri Envanteri" ve Çekici (2009) tarafından Türkçeye uyarlanan "Sosyal Problem Çözme Envanteri" yardımıyla toplanmıştır. Veriler bağımsız gruplar t-testi, tek yönlü varyans analizi (ANOVA), korelâsyon ve regresyon analizleri ile çözümlenmiştir. Öğretmenlerin politik becerileri ve problem çözme becerileri cinsiyet, eğitim düzeyi, kıdem ve okul kademesi değişkenlerine göre incelenmiştir. Bulgulara göre öğretmenlerin politik becerileri, cinsiyetlerine göre anlamlı farklılık gösterirken, öğretmenlerin problem çözme becerileri, cinsiyetlerine göre anlamlı farklılık göstermemektedir. Aynı zamanda öğretmenlerin politik becerilerinin ve problem çözme

\footnotetext{
* Bu çalışmanın bir kısmı ISOEVA-2019 kongresinde bildiri olarak sunulmuştur.
} 
becerilerin eğitim düzeyi, kıdem ve okul kademesi değişkenlerine göre anlamlı farklılık göstermediği tespit edilmiştir. Araştırma sonucuna göre öğretmenlerin politik becerileri ile problem çözme becerileri arasında düşük düzeyde ilişki olduğu saptanmıştır. Ayrıca politik becerilerin problem çözme becerilerini anlamlı şekilde yordadığı tespit edilmiştir.

Anahtar Kelimeler: Politik beceri, politik davranış, problem çözme becerisi.

\section{Abstract}

The aim of this study is to determine the relationship between teachers' political skills and problem solving skills. The sample of the research consists of 440 teachers working in public schools in Istanbul in 2018-2019 academic year. Correlational survey model was used as a research model. The data were collected with the help of "Political Skill Inventory" adapted to Turkish by Özdemir and Gören (2015) and "Social Problem Solving Inventory" adapted to Turkish by Çekici (2009). The data were analyzed by independent groups t-test, one way variance analysis (ANOVA), correlation and regression analysis. Teachers' political skills and problem-solving skills were examined according to gender, education level, seniority and school level variables. According to the findings, teachers 'political skills differ significantly according to their gender, while teachers' problem-solving skills do not differ significantly according to their gender. At the same time, it was found that teachers' political skills and problem solving skills did not differ significantly according to their educational level, seniority and school level variables. According to the results of the research, it was found that there was a low level relationship between teachers' political skills and problem solving skills. In addition, it was found that political skills significantly predicted problem solving skills.

Keywords: Political skills, political behavior, problem solving skills

\section{Giriş}

Evren ve dünya hayatının bir problem üzerine kurulduğu ve bu şekilde devam ettiği gözlenmektedir. İnsanoğlu dünyada geçirdiği süre boyunca problemlerle karşılaşır ve bunlara çözümler üretmeye çalışır. Bu süre zarfında hayatın her safhasında ihtiyaçların temin edilme aşamasını ve amaçların gerçekleştirilmesini engelleyen durumlar problem olarak tanımlanmaktadır (Taymaz, 2003). Başka bir ifadeyle problem, insanın veya örgütün içinde bulunduğu durum ile amaçları arasındaki farklılı̆̆ın meydana gelmesine sebep olan durumdur (D'Zurilla ve Nezu, 2010). Bireyin bir durumu problem olarak algılayabilmesi için ilk defa karşılaştığı ve çözüm bulabilmek için kendini hazır hissetmediği bir durum olması gerekmektedir (Kalayc1, 2001). Bireyin karşılaştığı her problem onun için bir gerginlik halidir (Öğülmüş, 2001) ve bu gerginliği ortadan kaldırmak için de probleme çözüm bulma ihtiyacı hissetmektedir (Özgenel, 2017).

Bireyin problemi tespit etmesiyle başlayıp hedefine ulaşana kadar geçirdiği süreç, problem çözme olarak ifade edilmektedir (Smith ve Kosslyn, 2014). Bingham'a (1971) göre problem çözme, karşılaşılan güçlükleri kontrol etme süreci olarak da tanımlanmıştır. Problem olarak görülen bir durumdan kaynaklı olumsuz duyguların değiştirilmesini ve iyileştirilmesini ilke edinen bilinçli, amaçlı ve rasyonel faaliyetler problem çözme olarak adlandırılabilir (D'Zurilla ve Nezu, 2010). Problem çözme, bir hedefe ulaşırken karşılaşılan engellere karşı uygulanan bilişsel işlemler kümesi (Smith 
ve Kosslyn, 2014) ve bu engellere çözüm getirme yeteneği olarak ifade edilebilir (Karakuş, 2001).

Problemlere etkili bir çözüm getirebilmek için genel olarak daha az siyah-beyaz ayrımı yapmaya istekli olmak, çok yönlü ve yaratıcı düşünme kalıpları kullanmak ve rasyonel seçenekler üretebilmek için zaman kazanmak gibi hususların yerine getirilmesi önerilmektedir (Hoy ve Miskel, 2012). Problem çözme sürecinde ilk olarak hedefler belirlenir, problem açık bir şekilde tanımlanır ve analiz edilir, problem çözümü için bilgi toplanır, daha sonra toplanan bilgiler yorumlanır ve analiz edilir, çözüm için seçenekler değerlendirilir ve strateji belirlenir, son olarak da çözümün sonuçları takip edilir (Paul ve Elder, 2013). Bu aşamalar sayesinde problemin anlaşılması ve çözümlenmesi kolaylaşmaktadır (Senemoğlu, 1997). Problemlere çözüm getirebilme, huzurlu bir yaşam sürme ve çevreye uyum sağlayabilme ancak bireyin problem çözme becerisine sahip olmasıyla mümkün olabilir (Kalaycl, 2001). Problem çözme becerisi, bireyin karşılaştığı problemi tanımlayabilme ve bu duruma karşı etkili çözümler üretebilme becerisi olarak ifade edilebilir (D'Zurilla ve Goldfried, 1971).

Problem çözme süreci, politik becerilerinde gerekli olduğu durumları meydana getirebilir. Söz konusu olan politik beceri; sosyal farkındalı̆̆ın gelişmesiyle beraber bireyler arasında gerçekleşen etkili iletişim biçimi olarak tanımlanabilir (Ferris vd., 2000). Politik becerisi yüksek olan bireylerin, çok iyi birer gözlemci ve analizci olduğu dile getirilmektedir (Cingöz, 2013). Politik beceri, kişinin başarıya ulaşmak için ihtiyacı olan gücü elinde bulundurmasıdır. Problem çözme ise bu gücü kullanarak karşılaşılan sorunlara çözümler sunabilme becerisidir.

Pfeffer, 1980'li yıllarda politik beceri kavramını, bir örgüte dahil olan bireyin başarıyı kazanmak için ihtiyaç duyulan gücü elde etmesi ve bu gücü geliştirmek amacıyla ortaya çıkardığı davranış örüntüleri olarak tanımlamış ve ilk defa literatüre kazandırmıştır (Akt., Ferris vd., 2007). Perrewé ve Nelson (2004) ise politik beceriyi, örgütteki diğer bireyleri anlayabilme yeteneği ve bu yeteneğin bireylerin örgütsel ve bireysel hedeflerinin geliştirilmesi için kullanılması olarak tanımlamıştır. Buna göre politik beceri hem doğuştan gelen hem de çevrenin etkisiyle oluşan bir beceri olarak düşünülebilir. Politik becerisi yüksek olan bireylerin, çevrelerinde güven duyulacak ve samimi bireyler olarak algılanacak seviyeye gelmeleri sosyal ve uyum sağlama becerilerini ne ölçüde kullandıklarını göstermektedir (Ferris vd., 2000).

Çok iyi bir gözlem ve analiz yeteneğine sahip olan bireylerin politik becerilerinin yüksek olduğu (Cingöz, 2013) ve bu beceri sayesinde iç denetim mekanizmalarını kullanarak başka insanlar üzerinde etki kurabildiği söylenebilir (Özdemir ve Gören, 2015). Bu beceriye sahip olan bireylerde iş ortamında kurulan iletişimin samimi bir şekilde nasıl gerçekleştirileceğine dair bilgilerinin yüksek olduğu düşünülmektedir (Bozkurt, 2019). Politik beceriye sahip olan bireylerin iletişim becerileri sadece yüz yüze iletişimi değil elektronik ortamda veya yazı diliyle iletişimi de kapsamaktadır. Bireyler duygularını zekice ve ikna edici bir şekilde ifade etme şansı bulabilirler (Ferris 
vd., 2000). İlgili literatür incelendiğinde politik beceri kavramının dört boyuta sahip olduğu belirtilmektedir (Ferris vd., 2007):

a) Sosyal zekâ: Genel hatlarıyla insanları anlama yeteneği olarak tanımlanan sosyal zekaya sahip bireylerin sezgi düzeyleri gelişmiş, güçlü bir idrak seviyesine sahip ve öz farkındalıklarının yüksek olduğu düşünülmektedir (Ferris vd., 2005; Blass ve Ferris, 2007; Atay, 2010).

b) Kişilerarası etki: Liu ve arkadaşlarının (2006) yaptığı tanıma göre insanları ve karşılaştıkları olayları zorlanmadan etkisi altına alabilme becerisi anlamına gelen kişilerarası etki becerisine sahip olan bireylerin nazik ve ikna edici bir dil kullanarak diğerlerinin davranışlarını değiştirebildiği söylenebilir (Bing vd., 2011).

c) İlişki ağı kurma becerisi: Bu beceriye sahip olan kişilerin arkadaşlık kurma, fırsat yaratma ve bu firsatlardan faydalanma (Perrewé ve Nelson, 2004) ve önemli kişilerle dostluklar kurarak bireysel ve örgütsel hedefleri geliştirmekte oldukça mahir oldukları ifade edilmektedir (Ferris, Davidson, Perrewé ve Atay, 2010).

d) Samimi görünme: Politik beceriye sahip olan kişiler açı bir güce sahip olmadıklarında etraflarında dürüst, samimi ve içten bireyler olarak algılanırlar (Jones, 1990).

Bir örgüt olarak okul, belli bir politikanın ve buna bağlı olarak da öğretmenler ve diğer çalışanlar tarafından gerçekleştirilen politik davranışları ve becerileri içeren eğitim sisteminin temel birimi olduğu söylenebilir. Bu bağlamda sergilenen politik davranışların, başta okul yöneticileri olmak üzere öğretmenler ve diğer çalışanlar tarafından okul ortamını etkilediği ileri sürülmektedir (Kılıç, 2013). Politik beceri kavramı yerine de kullanılabilen politik davranış, bireyin kişisel çıkarları doğrultusunda örgütteki hedeflerine ulaşmak için gösterdiği amaçlı davranışlar olarak tanımlanabilir (Seçkin, 2015). Politik davranış aynı zamanda bireyin kendi çıkarlarını önceleyerek örgütteki diğer üyelerin çıkarlarına ters düşecek sosyal bir etkileme süreci olarak da ifade edilebilir (Ariaei ve Beheshtifar, 2015).

Politik beceriler, doğuştan gelen bir yetenek olduğu gibi eğitim ve sosyalleşme yoluyla kazanılabilmektedir (Atay, 2010: 68). Bu bağlamda öğretmenlerin eğitim örgütlerinde istenen hazır bulunuşluk seviyesini sağlamak için etkili bir iletişim kurması ve buna bağlı olarak da politik becerilere sahip olması gerektiği düşünülmektedir. İlgili literatür tarandığında politik beceriler (Bostancı, Tosun, Gidiş ve Karaca, 2016; Özdemir ve Gören, 2016; Uğurlu ve Bostanc1, 2017; Kurt, 2018) ve problem çözme becerileri değişkenlerini ele alan birçok çalışmanın yapıldığ görülmektedir (Bal, 2011; Bağçeci ve Kinay, 2013; Çevik ve Özmaden, 2013; Çınar, Hatunoğlu ve Hatunoğlu, 2009; Demirtaş ve Dönmez, 2002; Pehlivan ve Konukman, 2004; Temel ve Ayan, 2015; Zembat, Tunçeli, ve Yavuz, 2017). Ancak alan yazın incelendiğinde öğretmenlerin politik becerileri ile problem çözme becerilerinin yüksek veya düşük olması halinde okullarda ne gibi faydalar veya zararlar sağlayacağı üzerine yapılan çok fazla araştırmaya rastlanmamıştır. Bu araştırma öğretmenlerin 
politik becerileri ile problem çözme becerileri arasındaki ilişkinin tespit edilmesi ve belirlenen demografik özellikler kapsamında öğretmenlerin politik becerilerinin problem çözme becerilerini yordayıp yordamağını analiz edilmesi yoluyla alana katkı sağlamayı amaçlamaktadır. $\mathrm{Bu}$ amaç doğrultusunda aşağıdaki sorulara yanıt aranmıştır;

1. Öğretmenlerin politik ve problem çözme becerileri ne düzeydedir?

2. Öğretmenlerin politik ve problem çözme becerileri cinsiyetlerine, eğitim durumlarına, görev yaptıkları okul kademelerine ve mesleki kıdemlerine göre anlamlı farklılık göstermekte midir?

3. Öğretmenlerin politik becerileri ile problem çözme becerileri arasında anlamlı bir ilişki var mıdır?

4. Öğretmenlerin politik becerileri, problem çözme becerilerini yordamakta midir?

\section{Yöntem}

\section{Araştırmanın modeli}

$\mathrm{Bu}$ araştırma, öğretmenlerin politik becerileri ile problem çözme becerileri arasındaki ilişkiyi belirlemek amacıyla nicel çalışma yöntemlerinden genel tarama modelinin bir alt türü olan ilişkisel tarama modeline göre yürütülmüştür. İlişkisel tarama modeli; iki ya da daha çok sayıdaki değişken arasında beraber değişime yönelim ya da örüntüsünü ifade etmek için uygulanan bir istatistiksel modeldir (Creswell, 2017).

\section{Araştırmanın evreni ve örneklemi}

Bu araştırmanın evrenini, 2018-2019 eğitim-öğretim yılında İstanbul ili Ümraniye ve Üsküdar ilçesinde kamu okullarında görev yapan öğretmenler oluşturmaktadır. Tabakalı örneklem yöntemiyle seçilen ilçelerden her okul kademesinden tesadüfi olarak 5'er tane okul seçilmiş ve bu okullarda gönüllü olarak katılan öğretmenler araştırmaya dahil edilmiştir. Tabakalı örnekleme yöntemi, evrendeki alt grupların belirlenmesi suretiyle bu grupların evren büyüklüğü içindeki oranlarının örneklem içinde temsil edilmesini hedefleyen örnekleme yöntemi olarak tanımlanabilir (Büyüköztürk, 2012).

Araştırmaya katılan 440 öğretmenin \%55'ini kadın \%45'ini erkek öğretmenler oluşturmaktadır. Öğretmenlerin \%45,9'u 6 yıldan az, \%23,1'i 7-12 yıl, \%16,1'i 13-18 yıl, $\% 9,31^{\prime} \mathrm{i} 19-24$ yıl ve $\% 4,77^{\prime}$ si ise 25 yıldan daha uzun süredir görev yapmaktadır. Araştırmaya katılan öğretmenlerin \%74'ü lisans düzeyinde iken, \%25,2'si lisansüstü düzeyde eğitim almışlardır. Öğretmenlerin \%14'ünün ilkokulda, \%35,4'ünün ortaokullarda ve \%50,4'ünün de lisede görev yaptıkları tespit edilmiştir. 


\section{Veri toplama araçları}

Araştırma verilerinin toplanmasında Kişisel Bilgiler Formu, Politik Beceriler Ölçeği (PBÖ) ve Sosyal Problem Çözme Becerisi Ölçeği olmak üzere toplam üç bölümden oluşan bir ölçek kullanılmıştır. Ölçeklerin izinleri önceden alınmış ve uygulanmıştır. Ölçekler uygulanırken verilerin gizli tutulacağı belirtilmiş ve tamamen gönüllülük esasına dayanarak seçilen öğretmenlerden yardım alınmıştır.

Politik beceriler ölçeği (PBÖ): Özdemir ve Gören (2015) tarafından Türkçeye uyarlaması yapılan Politik Beceriler Ölçeği (PBÖ), Ferris ve arkadaşları (2005) tarafından geliştirilmiştir. Ölçek 7'li likert tipinde olup dört alt boyuta sahiptir. Bu alt boyutlardan İlişki Kurma Becerisi boyutu 1-2-3-4-5-6; Kişilerarası Etki alt boyutu 15-1617-18; Sosyal Zekâ boyutu 10-11-12-13-14; Samimi Görünme boyutu ise 7-8-9. maddelerini içermektedir. Maddeler "Hiç katılmiyorum"(1), “Katılmiyorum" (2), “Kısmen katılıyorum" (3), “Katılıyorum" (4), “Oldukça katılıyorum” (5), “Güçlü bir şekilde katılıyorum" (6), "Tamamen katılıyorum" (7) şeklinde derecelendirilmiştir. Bu araştırmada ölçeğin Cronbach Alpha güvenirlik katsayısı 0.928 olarak hesaplanmıştır.

Sosyal Problem Çözme Becerisi Ölçeği: Sosyal Problem Çözme Envanteri-Kısa Formu (SPÇE-KF), Çekici (2009) tarafından Türkçe'ye uyarlanan, D'Zurilla ve Maydeu-Olivares (1995) tarafından geliştirilen ölçeğin geçerlik ve güvenirlik analizleri yapılmıştır. Ölçme aracı temelde "problem yönelimi (problem orientation)" ve "problem çözme tarzları (problem solving styles)" olmak üzere iki boyuttan ve problem çözme stili (tarzı) boyutunda ise, rasyonel problem çözme (rational problem solving), dikkatsiz/dürtüsel tarz (impulsitivity/carelessness styles), kaçınan tarz (avoidance styles) olmak üzere toplamda 5 alt boyuttan oluşmaktadır. Ölçekte toplam 25 madde yer almaktadır. Maddeler "Hiç uygun değil" (0), "Çok az uygun" (1), "Kısmen uygun" (2), "Çok uygun" (3) ve "Tamamen uygun" (4) şeklinde 5'li Likert olarak derecelendirilmiştir. Her bir alt boyuta ait toplam puan elde edilebildiği gibi ölçekten genel toplam puan da elde edilebilmektedir. Bu araştırmada ölçeğin Cronbach Alpha güvenirlik katsayısı 0.749 olarak hesaplanmıştır.

5’li ve 7’li Likert tipi ölçeklerin değerlendirilmesi aşamasında referans alınan puan aralıkları ve değerlendirilme düzeyleri Tablo 1'de verilmiştir.

Tablo 1. 5'li ve 7'li likert ölçek değerlendirmesi

\begin{tabular}{cccc}
\hline 5'li Puan Aralığı & Düzey & 7'li Puan Aralı̆̆1 & Düzey \\
\hline $00-0.79$ & Çok Düşük & $1.00-1.84$ & Çok Düşük \\
$0.80-1.59$ & Düşük & $1.85-2.69$ & Düşük \\
$1.60-2.39$ & Orta & $2.70-3.54$ & Ortanın Altı \\
$2.40-3.19$ & Yüksek & $3.55-4.39$ & Orta \\
$3.20-4.00$ & Çok Yüksek & $4.40-5.24$ & Ortanın üstü \\
& & $5.25-6.09$ & Yüksek \\
& & $6.10-7.00$ & Çok Yüksek \\
\hline
\end{tabular}




\section{Verilerin analizi}

Elde edilen veriler "SPSS" programı ile çözümlenmiştir. Verilerin normal dağılım gösterip göstermediğine karar vermek için Basıklık (Skewness) ve Çarpıklık (Kurtosis) değerleri hesaplanmış ve Tablo 2' de verilmiştir.

Tablo 2. Ölçeklere ait, aritmetik ortalama, stanadart sapma, basıklık ve çarpıklık değerleri

\begin{tabular}{lccccc}
\hline & $\mathrm{N}$ & $\bar{X}$ & Ss & Çarpıklık & Basıklık \\
\hline Problem Çözme Becerisi & 440 & 2.70 & .537 & -.214 & -.320 \\
Politik Beceriler & 440 & 4.76 & 1.024 & .023 & -.692 \\
\hline
\end{tabular}

Tablo 2 incelendiğinde ölçeklerin basıklık ve çarpıklık değerlerinin -1 ile +1 arasında yer aldığı ve normal dağılım gösterdiği anlaşılmaktadır. Dağılımların normal olduğunun tespit edilmesi üzerine parametrik testlerin uygulanmasına geçilmiştir. $\mathrm{Bu}$ bağlamda öğretmenlerin politik becerileri ve problem çözme becerilerinin cinsiyete ve eğitim durumuna göre farklılık olup olmadığını tespit etmek amacıyla t-testi; görev yaptıkları okul türleri ve mesleki kıdemlerine göre farklılık olup olmadığını tespit etmek amacıyla ise Tek Yönlü Varyans (ANOVA) analizi yapılmıştır.

Öğretmenlerin politik becerileri ile problem çözme becerileri arasındaki ilişkiyi belirlemek amacıyla Pearson Korelasyon testi kullanılmıştır. Politik becerilerin, problem çözme becerilerini yordayıp yordamadığını tespit etmek için basit regresyon analizi yapılmıştır.

\section{Bulgular}

Araştırmanın bu kısmında araştırma öğretmenlerin politik ve problem çözme becerilerinin aritmetik ortalama ve standart sapma değerleri Tablo 3'te yer almaktadır.

Tablo 3. Öğretmenlerin politik becerileri ve problem çözme becerilerinin aritmetik ortalama ve standart sapma değerleri

\begin{tabular}{lcccc}
\hline Değişkenler & $\mathrm{N}$ & $\bar{X}$ & ss & Değerlendirme \\
\hline $\begin{array}{l}\text { Problem Çözme } \\
\text { Becerisi }\end{array}$ & 440 & 2.70 & .537 & Yüksek \\
\hline Politik Beceriler & 440 & 4.76 & 1.024 & Yüksek \\
\hline
\end{tabular}

Tablo 3'te gösterildiği gibi öğretmenlerin politik ve problem çözme becerilerinin aritmetik ortalaması "yüksek düzeyde" bulunmuştur.

Kadın ve erkek öğretmenlerin politik ve problem çözme becerilerinin farklılık gösterip göstermediğini tespit etmek amacıyla yapılan bağımsız gruplar $t$ testi sonuçları Tablo 4 'te yer almaktadır. 
Tablo 4. Öğretmenlerin politik becerileri ve problem çözme becerilerinin cinsiyetlerine göre karşılaştırılması

\begin{tabular}{|c|c|c|c|c|c|c|c|}
\hline \multirow{3}{*}{$\begin{array}{l}\text { Değişkenler } \\
\text { Problem } \\
\text { Çözme } \\
\text { Becerisi }\end{array}$} & Gruplar & $\mathrm{N}$ & $\bar{X}$ & ss & $\mathrm{t}$ & $\mathrm{sd}$ & $\mathrm{p}$ \\
\hline & Kadın & 242 & 2.71 & .509 & \multirow[b]{2}{*}{.428} & \multirow[b]{2}{*}{438} & \multirow[b]{2}{*}{.669} \\
\hline & Erkek & 198 & 2.69 & .571 & & & \\
\hline Politik & Kadın & 242 & 4.57 & .966 & \multirow{2}{*}{-4.386} & \multirow{2}{*}{438} & \multirow{2}{*}{.000} \\
\hline Beceriler & Erkek & 198 & 5.00 & 1.048 & & & \\
\hline
\end{tabular}

Tablo 4'te yer alan bulgulara göre kadın ve erkek öğretmenlerin problem çözme

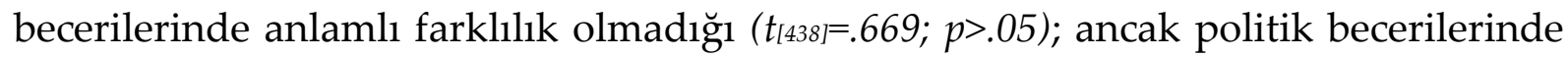

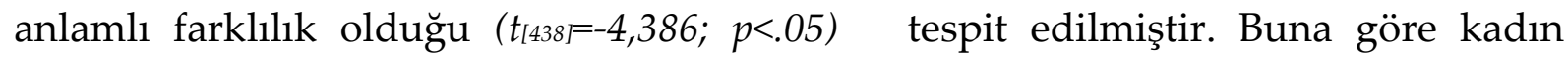
öğretmenlerin politik becerilerinin $(\bar{x}=4.57)$, erkek öğretmenlerin politik becerilerinden $(\bar{x}=5.00)$, daha az olduğu tespit edilmiştir.

Öğretmenlerin ĕgitim durumlarına göre politik ve problem çözme becerilerinin farklılık gösterip göstermediğini tespit etmek amacıyla uygulanan bağımsız gruplarda $t$ testi sonuçları Tablo 5'te yer almaktadır.

Tablo 5. Öğretmenlerin politik becerileri ve problem çözme becerilerinin eğitim durumlarına göre karşılaştırılması

\begin{tabular}{llcccccc}
\hline Değişkenler & Gruplar & $\mathrm{N}$ & $\bar{X}$ & $\mathrm{ss}$ & $\mathrm{t}$ & $\mathrm{sd}$ & $\mathrm{p}$ \\
\hline Problem & Lisans & 326 & 2.72 & .530 & & & \\
Çözme & Lisansüstü & 111 & 2.65 & .554 & 1.307 & 435 & .192 \\
Becerisi & Lisans & 326 & 4.75 & 1.032 & & & \\
\hline Politik & Lisansüstü & 111 & 4.80 & 1.000 & -.377 & 435 & .707 \\
Beceriler & & &
\end{tabular}

Tablo 5'te yer alan bulgulara göre öğretmenlerin eğitim durumlarına göre problem çözme ve politik becerilerinde anlamlı farklılık olmadığı görülmektedir ( $p>$.05). Bu bağlamda öğretmenlerin problem çözme ve politik becerilerinin, sahip oldukları lisans ve lisansüstü eğitim durumlarında farklılık göstermediği söylenebilir.

Öğretmenlerin okul kademesine göre politik ve problem çözme becerilerinin farklılık gösterip göstermediğini belirlemek amacıyla yapılan tek yönlü varyans (ANOVA) analizi sonuçları Tablo 6'da verilmiştir.

Tablo 6. Öğretmenlerin politik becerileri ve problem çözme becerilerinin görev yaptıkları okul kademelerine göre karşılaştırılması

\begin{tabular}{|c|c|c|c|c|c|c|c|c|c|c|c|}
\hline & $\begin{array}{c}\text { Okul } \\
\text { Kademesi }\end{array}$ & $\mathrm{N}$ & $\bar{X}$ & Ss & $\begin{array}{l}\text { Varyansın } \\
\text { Kaynağı }\end{array}$ & KT & $\mathrm{sd}$ & $\mathrm{KO}$ & $F$ & $\mathrm{p}$ & Anlamlılık \\
\hline \multirow{3}{*}{ 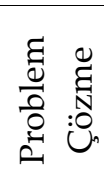 } & A-İlkokul & 62 & 2.58 & .529 & G. Aras1 & 1.11 & 2 & .556 & \multirow{3}{*}{1.935} & \multirow{3}{*}{.146} & \multirow{3}{*}{--- } \\
\hline & $\begin{array}{c}\text { B- } \\
\text { Ortaokul }\end{array}$ & 156 & 2.73 & .555 & G. İçi & 125.67 & 437 & .288 & & & \\
\hline & C-Lise & 222 & 2.72 & .524 & Toplam & 126.78 & 439 & & & & \\
\hline
\end{tabular}




\begin{tabular}{|c|c|c|c|c|c|c|c|c|c|c|c|}
\hline & Toplam & 440 & 2.70 & .537 & & & & & & & \\
\hline \multirow{4}{*}{ 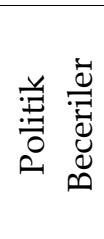 } & A-İlkokul & 62 & 4.75 & .961 & G. Aras1 & 1.366 & 2 & .683 & \multirow{4}{*}{.650} & \multirow{4}{*}{.523} & \multirow{4}{*}{--} \\
\hline & $\begin{array}{c}\text { B- } \\
\text { Ortaokul }\end{array}$ & 156 & 4.84 & 1.04 & G. İçi & 459.46 & 437 & 1.051 & & & \\
\hline & C-Lise & 222 & 4.72 & 1.02 & Toplam & 460.82 & 439 & & & & \\
\hline & Toplam & 440 & 4.76 & 1.02 & & & & & & & \\
\hline
\end{tabular}

Tablo 6'da verilen bulgulara göre öğretmenlerin problem çözme ve politik becerilerinde görev yaptıkları okul kademelerinde anlamlı farklılığın olmadığ edilmiştir ( $p>05)$. Öğretmenlerin kıdemlerine göre politik ve problem çözme becerilerinin farklılık gösterip göstermediğini tespit etmek amacıyla yapılan tek yönlü varyans (ANOVA) analizi sonuçları Tablo 7'de verilmiştir.

Tablo 7. Öğretmenlerin politik becerileri ve problem çözme becerilerinin kıdemlerine göre karşılaştırılması

\begin{tabular}{|c|c|c|c|c|c|c|c|c|c|c|c|}
\hline & Kıdem & $\mathrm{N}$ & $\bar{X}$ & Ss & $\begin{array}{c}\text { Varyansın } \\
\text { Kaynağ1 }\end{array}$ & KT & $\mathrm{sd}$ & $\mathrm{KO}$ & $\mathrm{F}$ & $\mathrm{p}$ & Anlamlılık \\
\hline \multirow{5}{*}{ 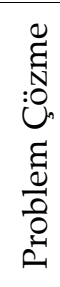 } & A-6 y1l ve altı & 202 & 2,73 & ,53 & G. Aras 1 & 2,20 & 3 & ,73 & \multirow{5}{*}{2,567} & \multirow{5}{*}{,054 } & \multirow{5}{*}{---} \\
\hline & B-7-12 y1l & 105 & 2,61 & ,49 & G. İçi & 124,58 & 436 & 28 & & & \\
\hline & C-13-18 y1l & 71 & 2,64 & ,61 & Toplam & 126,78 & 439 & & & & \\
\hline & $\begin{array}{l}\text { D-19 yıl ve } \\
\text { üzeri }\end{array}$ & 62 & 2,82 &, 51 & & & & & & & \\
\hline & Toplam & 440 & 2,70 & .53 & & & & & & & \\
\hline \multirow{5}{*}{ 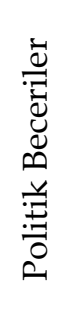 } & A-6 yıl ve altı & 202 & 4,84 & 1,03 & G. Arasi & 4,63 & 3 & 1,54 & \multirow{5}{*}{1,478} & \multirow{5}{*}{,220 } & \multirow{5}{*}{---} \\
\hline & B-7-12 y1l & 105 & 4,81 & 1,02 & G. İçi & 456,18 & 436 & 1,04 & & & \\
\hline & C-13-18 y1l & 71 & 4,67 & 1,07 & Toplam & 460,82 & 439 & & & & \\
\hline & $\begin{array}{l}\text { D-19 yll ve } \\
\text { üzeri }\end{array}$ & 62 & 4,55 & ,92 & & & & & & & \\
\hline & Top. & 440 & 4,76 & 1,02 & & & & & & & \\
\hline
\end{tabular}

Tablo 7'de verilen bilgilere göre öğretmenlerin problem çözme ve politik becerilerinde kıdemlerine göre anlamlı farklılık bulunamamıştır ( $p>05)$. Öğretmenlerin politik becerileri ile problem çözme becerileri arasındaki ilişkiyi ortaya koymaya yönelik uygulanan Pearson Korelasyon analizine ait sonuçlar Tablo 8'de gösterilmiştir.

Tablo 8. Öğretmenlerin politik becerileri ile problem çözme becerileri arastndaki korelasyon analizi sonuçları

\begin{tabular}{ccc}
\hline Değişkenler & & Problem Çözme Becerisi \\
\hline Politik Beceri & $\mathrm{r}$ & $.206^{* *}$ \\
& $\mathrm{p}$ & .000 \\
& $\mathrm{n}$ & 440 \\
\hline
\end{tabular}


Tablo 8 de verilen bulgulara göre öğretmenlerin politik becerileri ile problem çözme becerileri arasında düşük düzeyde ancak olumlu yönde anlamlı ilişki olduğu görülmektedir $(r=.206 ; p<.05)$. Değişkenler arasındaki korelasyon katsayıları 0-0.29 zayıf veya düşük, $0.30-0.64$ orta, 0.65-0.85 kuvvetli/yüksek ve 0.85-1.00 çok kuvvetli/çok yüksek şeklinde yorumlanmaktadır (Ural ve Kılıç, 2013).

Öğretmenlerin politik becerilerinin, problem çözme becerilerini yordayıp yordamadığına ilişkin basit regresyon analizi sonuçları Tablo 9' da gösterilmektedir.

Tablo 9. Öğretmenlerin politik becerilerinin problem çözme becerilerini yordayıp yordamadı̆̆ı̆na ilişkin basit regresyon analizi sonuçları

\begin{tabular}{|c|c|c|c|c|c|c|c|c|c|c|}
\hline B.s1z Değ. & B.11 Değ. & B & $\begin{array}{l}\text { Std. } \\
\text { Hata }\end{array}$ & $(\beta)$ & $\mathrm{t}$ & $p$ & $\mathrm{R}$ & $\mathrm{R}^{2}$ & $\mathrm{~F}$ & $p$ \\
\hline Sabit & \multirow{2}{*}{$\begin{array}{l}\text { Problem } \\
\text { Çözme } \\
\text { Becerisi }\end{array}$} & 2.191 & .120 & \multirow[b]{2}{*}{.206} & 18.314 & .000 & \multirow[b]{2}{*}{.206} & \multirow[b]{2}{*}{.043} & \multirow[b]{2}{*}{19.503} & \multirow[b]{2}{*}{.000} \\
\hline $\begin{array}{l}\text { Politik } \\
\text { Beceriler }\end{array}$ & & .108 & .025 & & 4.416 & .000 & & & & \\
\hline
\end{tabular}

Tablo 9'da verilen bulgular incelendiğinde öğretmenlerin politik becerileri, problem becerileri anlamlı bir şekilde yordadığ görülmektedir ( $p<.05)$. Öğretmenlerin politik becerileri, problem çözme becerilerinin \% $4^{\prime}$ ünü yordamaktadır $\left(\mathrm{r}=.206 ; \mathrm{r}^{2}=.043\right)$. Başka bir anlatımla problem çözme becerisindeki toplam varyansın \%4'ünü öğretmenlerin politik becerileri açılamaktadır. Diğer bir ifadeyle öğretmenlerin sahip olduğu politik beceriler, problem çözme becerilerini düşük düzeyde ve olumlu yönde etkilediği söylenebilir. Öğretmenlerin sahip olduğu politik becerilerin problem çözme becerilerini düşük düzeyde yordaması, problem çözme becerilerini etkileyen farklı değişkenlerin de olduğu anlamına gelebilir. Bu bağlamda problem çözme becerilerinin politik becerileri kapsadığı söylenebilir.

\section{Sonuç, Tartışma ve Öneriler}

$\mathrm{Bu}$ araştırmada, öğretmenlerin politik becerileri ile problem çözme becerileri arasında anlamlı bir ilişki olup olmadığının belirlenmesi ve öğretmenlerin politik becerilerinin problem çözme becerilerini yordayıp yordamadığının tespit edilmesi amaçlanmıştır. Araştırma sonucuna göre öğretmenlerin politik becerileri ve problem çözme becerilerinin "yüksek düzeyde" olduğu belirlenmiştir. Bu bulgular aynı zamanda öğretmenlerin politik becerilerinin yüksek olduğu sonucuna ulaşan diğer araştırmaları destekler niteliktedir (Bostancı, Tosun, Gidiş ve Karaca, 2016; Özdemir ve Gören, 2016; Uğurlu ve Bostanc1, 2017; Kurt, 2018). Buna göre okullarda eğitim görevinin önemli bir boyutunu üstlenen öğretmenlerin iletişim ve sosyal uyum anlamında politik becerilerini kullandıkları söylenebilir.

Öğretmenlerin politik becerilerinin cinsiyetlerine göre anlamlı farklılık gösterirken; mesleki kıdem, okul kademesi ve eğitim durumu değişkenlerinde anlamlı farklılı̆̆ın olmadığı belirlenmiştir. Bulgulara göre erkek öğretmenlerin politik 
becerilerinin kadın öğretmenlere göre daha fazla olduğu tespit edilmiştir. Erkek öğretmenlerin kadın öğretmenlere göre politik becerilerinin daha yüksek olduğu sonucuna ulaşan çalışmalar araştırmamız için destekleyici nitelik taşımaktadır (Bozkurt, 2019; Çıtak, 2011; Nair, 2018). Ayrıca eğitim durumunun öğretmenlerin politik becerileri üzerinde etkisiz kaldığını (Özdemir ve Gören, 2016; Kurt, 2018; Bozkurt, 2019); okul kademesi değişkeninde ilkokul, ortaokul ve lisede görev yapan öğretmenlerin politik becerilerinin birbirlerinden farklı olmadığını (Bozkurt, 2019; Kurt, 2018); mesleki kıdem değişkeninin öğretmenlerin politik becerilerini etkilemediğini (Yıldıztaşı, 2017; Kurt, 2018; Bozkurt, 2019) gösteren çalışmalara rastlamak mümkündür. Araştırma sonuçlarına bakıldığında erkek öğretmenlerin politik becerilerinin kadın öğretmenlerinkinden yüksek olmasının toplumsal yetiştirme tarzıyla alakalı olduğu düşünülebilir. Toplumun farklı cinsiyetler için biçtiği farklı roller bireyin sahip olduğu becerileri şekillendirebilmektedir. Aynı zamanda kişinin sahip olduğu politik becerisinde aldığı eğitim sayesinde bir ilerleme katedilmediği, yine çalıştıkları okullarda hitap ettikleri öğrenci kitlesinin yaş ve sınıf kademelerinde bu becerileri uygulama düzeylerinin etkisiz kaldığg söylenebilir. Bu araştırma bize mesleki tecrübe göz önüne alındığında yıllar geçtikçe bireyin sahip olduğu politik becerilerde bir değişikliğin olmadığını da göstermektedir.

Öğretmenlerin problem çözme becerilerinde demografik özelliklere göre anlamlı farklılık bulunamamıştır. Buna göre öğretmenlerin problem çözme becerileri; cinsiyetlerine (Bal, 2011; Bağçeci ve Kinay, 2013; Çevik ve Özmaden, 2013; Çınar, Hatunoğlu ve Hatunoğlu, 2009; Demirtaş ve Dönmez, 2002; Pehlivan ve Konukman, 2004; Temel ve Ayan, 2015; Zembat, Tunçeli, ve Yavuz, 2017), kıdemlerine (Karaca vd., 2013; Serin, 2006; Zembat, Tunçeli, ve Yavuz, 2017), okul kademesine (Sesli ve Bozgeyikli, 2015; Temel ve Ayan, 2015) ve eğitim durumlarına (Özğül, 2009; Sevgi, 2004; Tavlı, 2009; Temel ve Ayan, 2015; Zembat, Tunçeli, ve Yavuz, 2017) göre anlamlı şekilde farklılaşmadığı söylenebilir. Sonuç olarak öğretmenlerin meslek hayatına başlamadan önce veya devam ederken edindikleri eğitim seviyelerindeki değişmenin, icra ettikleri meslekte geçirdikleri uzun yılların ve hitap ettikleri kitleye bağlı olarak değişen kademelerin sahip oldukları problem çözme becerisini olumlu veya olumsuz olarak etkilemediği anlaşılmıştır. Aynı şekilde bireyin sahip olduğu bu becerinin cinsiyete göre değişmediğini de söylemek mümkündür.

Öğretmenlerin politik becerileri ile problem çözme becerileri arasında pozitif yönde ve düşük düzeyde anlamlı bir ilişki olduğu tespit edilmiştir. Aynı zamanda öğretmenlerin politik becerilerinin problem çözme becerilerini anlamlı şekilde yordadığı sonucuna ulaşılmıştır. Bu bağlamda, öğretmenlerin bulundukları okullarda samimi ve içten davranışları, hızlı karar verebilme ve meslektaşları tarafından güvenilme noktasında sahip oldukları politik beceriler, karşılaştıkları problemlerin çözümünü etkilemektedir. Bahsi geçen etki olumlu ancak düşük düzeyde bir etkidir. Politik beceriye sahip olan bireyler hızlı karar alabilme noktasında yetkin oldukları için karşılaştıkları problemlere daha kolay çözümler getirebilirler. Aynı zamanda politik becerilerin karşısındaki kişiyi etkisi altına alabilme becerisi olması, kurulan 
sağlıklı iletişim ve samimi davranış sonucunda problemlerin çözümüne olumlu katkılar sağladığı düşünülebilir. İyi bir gözlem ve analiz yeteneğini içinde barındıran politik beceriye sahip olan bir öğretmenin okulda yaşanılan çatışmalara rasyonel çözümler getirebileceği ve uyum sağlama becerisi sayesinde çözüm bulduğu problemlerle huzurlu bir okul ortamının oluşmasında etkili olabileceği tahmin edilmektedir. Bu bağlamda öğretmenlerin farklı becerilerinin geliştirici eğitimler alması teşvik edilebilir.

$\mathrm{Bu}$ araştırma nicel araştırma yöntemiyle yapıldığı için öğretmenlerin anketlere verdikleri cevaplarla sınırlı kalmışır. Bir sonraki araştırmalar daha kapsamlı bir veri ortaya koymak amacıyla karma desen tercih edilerek yapılabilir. Çalışmada öğretmenlerin sahip olduğu politik beceriler ve problem çözme becerileri üzerinde durulmuştur. Ancak öğretmenlerin bu politik ve problem çözme becerilerinin nasıl geliştirileceği, politik ve problem çözme becerilerinin artması için ne tür faaliyetlere ihtiyaç olacağı üzerinde bir görüş beyan edilmemiştir. Gelecekteki çalışmalar öğretmenlerin politik ve problem çözme becerilerinin geliştirilmesi için neler yapılması gerektiğini konu edinebilir.

\section{Etik Beyan}

“Öğretmenlerin Politik Becerileri ile Problem Çözme Becerileri Arasındaki İlişki" başlıklı çalışmanın yazım sürecinde bilimsel, etik ve alıntı kurallarına uyulmuş; toplanan veriler üzerinde herhangi bir tahrifat yapılmamış ve bu çalışma herhangi başka bir akademik yayın ortamına değerlendirme için gönderilmemiştir.

\section{Kaynaklar}

Atay, S. (2010). Geliştirilebilir yönetim becerisi: Teorik ve ampirik yönleriyle "Politik Yeti". Amme İdaresi Dergisi, 43(2), 65-80.

Bağçeci, B. \& Kinay, İ. (2013). Öğretmenlerin problem çözme becerilerinin bazı değişkenlere göre incelenmesi. Elektronik Sosyal Bilimler Dergisi, 12(44), 335-347.

Bal, M. (2011). Okul öncesi öğretmenlerinin problem çözme becerileri ile eleştirel düşünme eğilimleri arasındaki ilişkinin incelenmesi. Yüksek lisans tezi, Abant İzzet Baysal Üniversitesi Sosyal Bilimler Enstitüsü, Bolu.

Bing, M. N., Davison, H. K., Minor, I., Novicevic, M. M. \& Frink, D. D. (2011). The prediction of task and contextual performance by political skill: A meta-analysis and moderator test. Journal of Vocational Behavior, 79(2), 563-577.

Bingham, A. (1971). Çocuklarda problem çözme yeteneklerinin geliştirilmesi (F. Oğuzkan, Çev.). Millî Eğitim Bakanlığı.

Blass, F. R. \& Ferris, G. R. (2007). Leader reputation: the role of mentoring, political skill, contextual learning and adaptation. Human Resource Management, 46(1), 5-19. 
Bostanc1, A. B., Tosun, A., Gidiş, Y. \& Karaca, O. (2016). Öğretmenlerin politik yetileri ile akademik iyimserlikleri ve işe karşı olumlu duygu durumları arasındaki ilişki. 3nd Eurasian Educational Research Congress. Muğla Sitkı Koçman Üniversitesi, Muğla.

Bozkurt, B. N. (2019). Okul mutluluğunu etkileyen bir faktör: Öğretmenlerin politik becerileri. Yüksek lisans tezi, Sabahattin Zaim Üniversitesi Sosyal Bilimler Enstitüsü Eğitim Yönetimi Ana Bilim Dalı. İstanbul.

Büyüköztürk, Ş. (2012). Sosyal bilimler için veri analizi el kitabı. (17. Bs.). Pegem Yayıncılık.

Cingöz, A. (2013). Politik yetenekler ve öz-yönlendirmenin (kendini kurgulamanın) algılanan kariyer başarısı üzerindeki etkisini belirlemeye yönelik bir araştırma. Selçuk Üniversitesi İktisadi ve İdari Bilimler Dergisi, 13(26), 153-179.

Creswell, J. W. (2017). Eğitim araştırmaları: Nicel ve nitel araştırmanın planlanması, yürütülmesi ve değerlendirilmesi. Edam.

Çekici, F. (2009). Problem çözme terapisine dayalı beceri geliştirme grubunun üniversite öğrencilerinin sosyal problem çözme becerileri, öfkeyle ilişkili davranış ve düşünceler ile sürekli kaygı düzeylerine etkisi. Yayınlanmamış doktora tezi, Çukurova Üniversitesi, Sosyal Bilimler Enstitüsü, Ankara.

Çevik, D. B. \& Özmaden, M. (2013). Öğretmen adaylarının problem çözme becerileri. Journal of Research in Education and Teaching, 2(3), 270-275.

Çınar, O., Hatunoğlu, A. \& Hatunoğlu, Y. (2009). Öğretmenlerin problem çözme becerileri. Erzincan Ĕ̆itim Fakültesi Dergisi, 11(2).

Çıtak, M. (2011). Politik yeti ve örgütsel bă̆gllık arasındaki ilişki: Yöneticiler üzerine bir araştırma. Yüksek lisans tezi, Marmara Üniversitesi Sosyal Bilimler Enstitüsü, İstanbul.

D'Zurilla, T. \& Goldfried, M. R. (1971). Problem solving and behavior modification. Journal of Abnormal Psychology, 78(1), 107-126.

D'Zurilla, T. \& Maydeu-Olivares, A. (1995). Conceptual and methodological issues in social problem-solving assessment. Behavior Therapy, 26, 409-432.

D'Zurilla, T. \& Nezu, A. M. (2010). Problem solving therapy. In K. S. Dobson (Ed.), Handbook of cognitive behavioral therapies. New York: Guilford Press.

Demirtaş, H. \& Dönmez, B. (2002). Ortaöğretimde görev yapan öğretmenlerin problem çözme becerilerine ilişkin algıları. İnönü Üniversitesi Ĕ̆itim Fakültesi Dergisi, 9(1) 6, 177 198.

Ferris, G. R., Davidson, S. L., Perrewe', P. L. \& Atay, S. (2010). İş yaşamında politik yeti (2. Bs.). Namar Yayınları.

Ferris, G. R., Perrewé, P. L., Anthony, W. P. \& Gilmore, D. C. (2000). Political skill at work. Organizational Dynamics, 28(4), 25-37.

Ferris, G. R., Russ, G. S. \& Fandt, P. M. (1989). Politics in organizations. In: Giacalone RA, (Rosenfeld P, Ed.). Impresion Management in The Organization, Hillsdale, NJ: Lawrence Erlbaum, 143-70. 
Ferris, G. R., Treadway, D. C., Kolodinsky, R. W., Hochwarter, W. A., Kacmar, C. J. \& Douglas, C. (2005). Development and validation of the political skill inventory. Journal of Management, 31(1), 126-152.

Ferris, G. R., Treadway, D. C., Perrewé, P. L., Brouer, R. L., Douglas, C. \& Lux, S. (2007). Political skill in organizations. Journal of Management, 33(3), 290-320.

Hoy, K. W. \& Miskel, C. G. (2012). Eğitim yönetimi teori, araştırma ve uygulama (S. Turan, Çev.). Nobel.

Kalaycı, N. (2001). Sosyal bilimlerde problem çözme ve uygulamalar. Gazi.

Karaca, N. H., Aral, N. \& Karaca, L. (2013). Okul öncesi öğretmenlerinin problem çözme becerisi ve benlik saygısının incelenmesi. Eğitim ve Öğretim Araştırmaları Dergisi, 2 $3)$.

Karakuş, M. (2001). Eğitim ve yaratıcılık. Ĕ̆itim ve Bilim, 26(119), 3-7.

Kılıç, M. A. (2013). Bir eğitim yöneticisinin günlü̆̆̈̈̈. Marmara Üniversitesi 8. Ulusal Eğitim Yönetimi Kongresi Bildiri Özetleri, Marmara Üniversitesi Yayınları, 27-28.

Kurt, Ş. (2018). Öğretmenlerin politik yetileri ile akademik iyimserlik düzeyleri arasındaki ilişki. Yüksek lisans tezi, Uşak Üniversitesi Sosyal Bilimler Enstitüsü, Uşak.

Liu, Y., Ferris, G. R., Treadway, D. C., Prati, M. L., Perrewé, P. L. \& Hochwarter, W. A. (2006). The emotion of politics and the politics of emotions: Affective and cognitive reactions to politics as a stressor. Vigoda-Gadot, E. \& A. Drory (Ed.). Handbook of Organizational Politics. MPG Books Ltd.. Great Britain. 161-186.

Nair, A. (2018). Okul müdürlerinin liderlik stilleri ile politik becerileri arasındaki ilişki (Tekirdă̆g Örneği). Yüksek lisans tezi, İstanbul Sabahattin Zaim Üniversitesi Sosyal Bilimler Enstitüsü, İstanbul.

Öğülmüş, S. (2001). Kişilerarası sorun çözme becerileri ve eğitim. Nobel.

Özdemir, M. \& Gören, S. Ç. (2015). Politik beceri envanterinin eğitim örgütlerinde geçerlik ve güvenirlik çalışmaları. Kuram ve Uygulamada Eğitim Yönetimi, 21(4), 521-536.

Özdemir, M. \& Gören, S. Ç. (2016). Politik beceri ve psikolojik sermaye arasındaki ilişkinin öğretmen görüşlerine göre incelenmesi. Hacettepe Üniversitesi Ĕ̆itim Fakültesi Dergisi, 31(2), 333-345.

Özgenel, M. (2017). Okul yöneticilerinin yaratıcı ve eleştirel düşünme eğilimleri ile karar verme stilleri ve problem çözme becerileri arasındaki ilişkiler örüntüsü. Doktora tezi, Marmara Üniversitesi Sabahattin Zaim Üniversitesi Eğitim Yönetimi ve Denetimi Ortak Doktora Programı. İstanbul.

Özğül, E. (2009). Okul öncesi öğretmenlerinin problem çözme becerileri ile öğretmenlik tutumları arasındaki ilişkinin incelenmesi (Uşak ili örneği). Yüksek lisans tezi, Abant İzzet Baysal Üniversitesi Sosyal Bilimler Enstitüsü, Bolu.

Paul, R. \& Elder, L. (2013). Eleştirel düşünme (A. E. Aslan ve G. Sart, Çev. Ed.). Nobel.

Pehlivan, Z. \& Konukman F. (2004). Beden eğitimi öğretmenleri ile diğer branş öğretmenlerinin problem çözme becerisi açısından karşılaştırılması. Spormetre Beden Eğitimi ve Spor Bilimleri Dergisi, 2(2), 55-60. 
Perrewe, P. L. \& Nelson, D. L. (2004). Gender and career success: The facilitative role of political skill. Organizational Dynamics, 33(4), 366-378.

Seçkin, Ş. N. (2015). Tepe yöneticilerin kişilik özellikleri, güç temelleri ve politik davranışlarının örgütsel politika algısına etkisi. Doktora tezi, İnönü Üniversitesi Sosyal Bilimler Enstitüsü İşletme Anabilim Dalı Yönetim Organizasyon Bilim Dalı, Malatya.

Senemoğlu, N. (1997). Gelişim, öğrenme ve öğretim. Ertem.

Serin, O. (2006). Sınıf öğretmenlerinin problem çözme becerilerinin çeşitli değişkenler açısından incelenmesi. Eğitim ve Bilim Dergisi, 31(142), 80-88.

Sesli, S. \& Bozgeyikli, H. (2015). Okul öncesi öğretmenlerinin problem çözme becerileri ile disiplin anlayışlarının incelenmesi. Türkiye Sosyal Politika ve Çalışma Hayatı Araştırmaları Dergisi, 5(8).

Sevgi, M. (2004). Illköğretim ve lise yöneticilerinin sorun çözmeye ilişkin tutumları. Yayımlanmamış yüksek lisans tezi, Abant İzzet Baysal Üniversitesi Sosyal Bilimler Enstitüsü, Bolu.

Smith, E. E. \& Kosslyn, S. M. (2014). Bilişsel psikoloji: Zihin ve beyin (M. Şahin, Çev.). Nobel.

Tavlı, O. (2009). Lise öğretmenlerinin problem çözme becerileri ile tükenmişlikleri arasındaki ilişkinin incelenmesi. Yüksek lisans tezi, Yeditepe Üniversitesi Sosyal Bilimler Enstitüsü, İstanbul.

Taymaz, H. (2003). Okul yönetimi. Pegem A.

Temel, V. \& Ayan, V. (2015). Beden eğitimi ve spor öğretmenlerinin problem çözme becerileri. KMÜ Sosyal ve Ekonomik Araştırmalar Dergisi, 17(29), 70-76.

Uğurlu, E. \& Bostancı, A. B. (2017). Öğretmenlerin politik yetileri ile örgütsel muhalefet düzeyleri arasındaki ilişki. Journal of Sciences, 14(4), 4050-4064.

Ural, A. \& Kılıç, İ. (2013). Bilimsel araştırma süreci ve SPSS ile veri analizi. Detay.

Yıldıztaşı, M. B. (2017). Politik beceri ile örgütsel tükenmişlik ilişkisinin ortaokul öğretmenlerinin görüşlerine göre incelenmesi (Yalova ili örneği). Yüksek lisans tezi, Hacettepe Üniversitesi Eğitim Bilimleri Anabilim Dalı Eğitim Yönetimi, Teftişi, Planlaması ve Ekonomisi Bilim Dalı, Ankara.

Zembat, R., Tunçeli, H. İ. \& Yavuz, E. A. (2017). Okul öncesi öğretmenlerinin sınıf yönetimi becerileri ile problem çözme becerileri arasındaki ilişkinin incelenmesi. Ahi Evran Universitesi Kırşehir Ĕ̆itim Fakültesi Dergisi, 18(3). 